Candidate of philological sciences, associate professor English Language Department Dnipropetrovsk National University of Railway Transport

I. Shpak

Candidate of philological sciences, associate professor English Language Department Dnipropetrovsk National University of Railway Transport

\title{
A SECRET HISTORY: CHARACTER ANALYSIS
}

Problem statement. In modern linguistics and stylistics, interest to the study of artistic image is traditionally considered to be one of the conceptual. The notion of artistic image is used as a term in various branches of knowledge. In philosophy, the image is understood as any reflection of reality, whether conceptual or sensual; in psychology, the image is a synonym of representation, that is, the imaginary contemplation of an object in its integrity; in aesthetics it is a reproduction of the integrity of an object in a certain system of signs. The material carrier of imagery in fiction is the word, language [5, p. 441]. The artistic image is one of the most versatile and complex ethical categories used in a number of humanities. Herewith, in each case, the directions of consideration, understanding and definition of this category change.

Formulation of aims. The aim of this piece is an attempt to research artistic images in the novel "A Secret History" by Donna Tartt.

Method: The synthetic approach to the study of stylistic means, which is becoming relevant for modern philology, is used in the current investigation. The postmodern fiction states the death of the author and thus the dynamics between literary concepts and images shifted in such a way that stylistic techniques has become one of the expressive means. Today fiction became a reality for both the author (when he or she is writing the text and gives it primary meaning) and the reader (when he or she interprets it and gives it secondary meanings)

Analysis of recent research and publications. The active interest in the phenomenon of artistic image began in the XVIII century. It is associated with the names of A. Shaftesbury, G.E. Lessing, D. Diderot and others. The artistic image is the result of the reconstruction of the object in the human consciousness; the concept that is an integral part of philosophical, psychological, sociological and aesthetic discourses [12, p.73].

Analysis of the construction of the image, its functioning and development - the prerogative of psychology, which considers it as a process that plays an important role in the system of mental regulation of human activity. The image embodies the essence of the psychic. In naturalistic versions of epistemology the image is represented in feelings, external properties, connections, spatial-temporal relations of objects, which are determined by direct interaction with the object [9].

The notion of artistic image owes its birth to fiction, where language becomes both a means and a subject of art. The language itself is a work of art [3, p. 246].

Artistic language has its own value precisely because it is not just a form, but also a certain content, which became the form of the image [4, p. 46]. Thus, content, expressed in an audio form (word), serves as a form of different content (image). However, the very concept of image is broader than artistic image. A verbal image can be used in other types of literature; its value can be defined as a form of visual representation of reality. The artistic image is distinguished by the fact that it represents a method of concrete-sensual reproduction of reality from the standpoint of a certain aesthetic ideal [11, p. 15].

As Alexei Losev points out, in order to have an image of something, it is necessary to consciously separate oneself from the other, because the image is a conscious orientation to another and a conscious restraint from this other, when the subject, using the material of another, is already trying to do without this other in the future [7, p. 8].

The artistic image serves as a way of understanding the world and the language of art [1]. The classical definition of art as thinking in images goes back to Hegel's aesthetics, in which such important philosophical dominant artistic images as the ideal and concreteness, which are the embodiment of the ideal and the canon in the material of art are distinguished $[10$, p. 29]. From Aristotle, the artistic image is seen as means of forming a new reality, thus, the area of probability, and its embodiment is one of the higher forms of creative activity [6].

Statement of the basic material. The artistic image has many forms: images of people, pictures of nature, urban landscapes, and images of things reproduced with the help of imagination, put into new relationships through the constructive thinking of the author [2, p. 176]. At the same time, the meaning of the artistic image is revealed only in a certain communicative situation, and the end result of such communication depends on the person, the goals and even the mood of man, as well as on the specific culture to which he belongs [8]. Therefore, often after one or two centuries since the creation of a work of art, it is perceived not exactly like it was perceived by his contemporaries and even the author himself.

Donna Tartt (Donna Louise Tartt) was born in December, 23, in Greenwood, Mississippi. Her most notable literary works are "A Secret History" (her debut novel) and "The Goldfinch". She wrote "A Secret History" in 1992 and "The Goldfinch" in 2013, the book which became winner of 2014 Pulitzer Prize for fiction. Toward the end of the $20^{\text {th }}$ century, when working on the novel "A Secret History" Donna Tartt was connected to the "literary brat pack," a young, East Coast 
group of writers whose tales of drug use and disaffection were, in the late 80s and early 90s, a by-word for literary cool. It was rumored that Bret Easton Ellis, one of the leaders of the group, was Donna Tartt's friend and they studied together at Bennington College in Vermont. She started to write her debut novel in Bennington and again it was rumored that she used her co-eds as models for the characters of the book.

Basically, the story is an inverted detective story, not whodunit, but whydunit. The traditional detective story sets the task for the reader to solve the mystery/crime along with the detective (officer of the law or private investigator, professional or amateur sleuth, regardless). In the traditional story the reader is somewhat disadvantaged (the detective solves the mystery and then explains the reader "who did it", "why he did it" and "how he did it"). In the reversed detective story the reader has the advantage, he or she is the first "to see" the crime being committed or the first to find out about the crime, and the detective is lagging behind in such a case because of lack of initial information regarding the crime. Thus a question presents itself for the reader: how will the detective manage to solve a perfect crime? As far as, due to the laws of suspense one might assume that the crime should be a perfect one or almost perfect one.

"The Snow in the mountains was melting and Bunny had been dead for several weeks before we came to understand the gravity of our situation. He'd been dead for ten days before they found him, you know. It was one of the biggest manhunts in Vermont history- state troopers, the FBI, even an army helicopter; the college closed, the dye factory in Hampden shut down, people coming from New Hampshire, upstate New York, as far away as Boston...” [13; p. 12]

An auspicious reverse detective story requires both intelligent antagonist and protagonist. Speaking of which, the thinner the line between those characters is, the more successful is the story. In the reversed detective story it is not easy to differentiate actions of the characters applying the black and white principle.

"A Secret History" deals with not just one main character, but with five for each murder separately and the total of the characters is six. They all had reasons to commit the crimes they committed; however it is with the reader's discretion to accept those reasons as plausible ones or not. The moral aspects is nonetheless important, though is not the matter of this particular discussion. Only the reader has the power either to convict or justify the main characters. In our opinion the author of the novel could not decide whether those students deserved punishment, thus she left it for the reader to be the supreme judge of the story.

The novel deals with lives of many characters, but we are primarily interested in six: Richard Papen, Henry Winter, Francis Abernathy, Bunny Corcoran, and Camila and Charles Macauley. Richard is the narrator of the story, and it is logical to assume that according to the author's vision he might have the most enigmatic personality. However as the reader proceeds with the plunging into the story, he or she may feel that it may not be the case for many reasons.

Richard Papen: a 19-yearold who is desperately trying to fit in, to escape his mediocre useless being and become prosperous and successful. He is doing two undergraduate years in medical college, hates medicine, but as far as it is the only possible profession for him, which can be lucrative in the future, he is doing a medical course. He is everyone: every reader may easily see himself or herself in Richard Papen. He is the main character of "The Catcher in the Rye", "The Great Gatsby", etc. He represents escape from tediousness, from boredom, from vanity and shame of a mediocre life and into the light of something new and exciting:

"On leaving home I was able to fabricate a new and far more satisfying history, full of striking, simplistic environmental influences; a colorful past, easily accessible to strangers." [13; p. 47]

Being from a partly dysfunctional family, he is naturally looking for love and acceptance. He is mesmerized by the "Greek group" and wants to get inside for whatever it takes. He crosses the line of morale and starts fabricating his new identity. In these first pages the reader may see that Richard does not see a problem about lying to achieve something he wants, but the question still remains: having crossed the line how far is he going to go.

Francis Abernathy: a Greek scholar with a solid trust fund. Using Francis's character Tartt raises the problem of homosexuality, which at that time was a rather acute one. It can be said that Francis was the most moral one among all the group members, if the reader applies Judeo-Christian moral. On the other hand one must keep in mind that the philosophical background of the book is rather Greek philosophy than Judeo-Christian moral.

"The Furies,' said Bunny, his eyes dazzled and lost beneath the bang of hair. 'Exactly. And how did they drive people mad? They turned up the volume of the inner monologue, magnified qualities already present to great excess, made people so much themselves that they couldn't stand it." [13; p. 81]

After Bunny's murder Francis starts having panic attacks and he even attempts to committee a suicide after his grandfather threatens to cut him out the will unless Francis gets married. Overall, Francis may be considered as a respectable, though quite a weak man.

Camilla and Charles Macaulay: Tartt doesn't deem to dwell on the twins' characters in much detail, though it is Camilla who triggers the chain of events that leads to tragedy, inevitably logical, but still to some extent unacceptable. Camilla is very independent and strong; she doesn't share much and hides uncomfortable details of her relationships with Charles, which is incest for that matter. She is the only female in the group and the rest tend to gravitate towards her. Charles is spontaneous, frivolous, and prone to addictions, eventually he becomes an abusive alcoholic, but he does not care much about other people opinion:

"And then there were a pair, boy and girl. I saw them together a great deal, and at first I thought they were boyfriend and girlfriend, until one day I saw them up close and realized they had to be siblings. Later I learned they were twins. They looked very much alike, with heavy dark-blond hair and epicene faces as clear, as cheerful and grave, as a couple of Flemish angels. And perhaps most unusual in the context of Hampden--where pseudo-intellects and teenage decadents abounded, and where black clothing was deregueur-- they liked to wear pale clothes, particularly white. In this swarm of cigarettes and dark sophistication they appeared here and there like figures from an allegory, or long-dead celebrants. " [13; p. 57] 
Bunny Corcoran: as all the characters of the book Bunny has many sides. He is in some aspects like Richard, though he has quite different motifs. He lies about his financial state, but not because he wants to befriend people but because he wants to use them, he wants to live at their expense. Finding out about the predicament of his friends, moral values play no role for Bunny (at least in the beginning), he realizes that he can use this situation to improve him financial situation, On the outside Bunny is a perfectly likable and agreeable character however, on the inside his character is full of snide, malice and envy. Bunny is an absolutely shallow character who hides under the mask of an intelligent scholar:

"I think, because in spite of my good-natured laughter he must have been dimly aware that he was touching a nerve, that I was in fact incredibly self-conscious about these virtually imperceptible differences of dress and of the rather less imperceptible differences of manner and bearing between myself and the rest of them." [13; p. 278]

Henry Winter: Henry is probably the second mysterious character after Julian, and the most mysterious among the students. He can perfectly interact with others (mostly on the condition of those people being somewhat intelligent according to his scale), but there is an absolutely different personality within his consciousness. Throughout the novel his character remains a mystery his ideas and intentions can be read in several ways, thus they also remain unclear to the others.

"Henry didn't say anything, and I'm sure that at that moment he would have looked perfectly impassive to anyone who didn't' know him, but I could tell he was quite agitated." [13; p. 309]

In the end Henry kills himself for reasons speculated. He may have killed himself to save Charles, he may have killed himself, because he could not forgive Julian or for a number of other reasons, though it is hardly to believe that those reasons could be either material or practical. Moreover, there is still the mystery of his final words that he told Camilla:

"It wasn't from desperation that he did it. Nor, I think, was it fear. The business with Julian was heavy on his mind; it had impressed him deeply. [13; p. 511]

"A Secret History" is a novel where the reader finds out about two murders and a suicide. At some point Bunny's search gets on a huge scale, involving not only state police, but the FBI as well. However, law enforcement agents leave as soon it becomes clear that there was no foul play and Bunny's death was an accident. And this is exactly the point where the reader can feel deceived: the murder, in fact two murders are not solved, the culprits are at large, there are people who know about the murders, but who are unwilling to step forward and give the names of the culprits. Or is he not? "A Secret History" is a novel with a number of attributes of the inverted detective story, possibly created by R. Austin Freeman, but it is nevertheless a philosophical novel with a number of rather high matters such as losing one's self, eternal escape, subconsciousness, crime and punishment, Jacobean dramatics, etc.:

"I hope we're all ready to leave the phenomenal world, and enter into the sublime?" says Julian Morrow, professor of ancient Greek, at the beginning of Richard's first lesson with him." [13; p. 71]

The novel is characterized by the breath of supernatural, mysterious and mystique. The tension is building slowly and the reader is being skillfully manipulated, everything is measured and perfectly executed.

Conclusion. Today the synthetic approach to the study of stylistic means is becoming topical for contemporary philology. The dynamics of the relation between the concepts has shifted towards convergence so that stylistic techniques become one with the expressive means, because in postmodern poetry (fiction), which states the death of the author, stylistic means are created both during the writing of the text by the author and during its interpretation by the reader. Nowadays there is no clear definition of terminology; their inter-relationship depends on the approach to understanding concepts of literary images; the fuzzy boundary between these concepts begins to blur in connection with the emergence of new linguistic means that combine the features of both expressive means and stylistic techniques. Apart from the importance of purely stylistic techniques (tropes) used for the creating of the artistic image, it is getting much wider meaning these day, there is shift from technical tropes use to creating linguistic and psychological concepts for the reader.

\section{References:}

1. Бахтин М.М. Эстетика словесного творчества. Москва, 1979. 423 с.

2. Беляев Н.И. Образ человека в изобразительном искусстве: индивидуальное и типичное. Вестник Оренбургского государственного университета. 2007. № 7. С. 176.

3. Винокур Г.О. Избранные работы по русскому языку. Москва, 1959. $450 \mathrm{c.}$

4. Кожинов В.В. Слово как форма образа. Слово и образ : сб. статей. Москва, 1964. С. 46.

5. Кожинов В.В. Типическое. Литературный энциклопедический словарь. Москва, 1987. С. 441.

6. Коршунов А.М. Категория познавательного образа. Теория познания : в 4 т. Москва, 1991. Т. 2 : Социально-культурная природа познания. С. 20-50.

7. Лосев А.Ф. Философия имени. Москва : МГУ, 1990. 300 с.

8. Николаев А.И. Основы литературоведения : учебное пособие для студентов филологических специальностей. Иваново : ЛИСТОС, 2011. 255 с.

9. Новая философская энциклопедия : в 4 т. / под ред. В.С. Стёпина. Москва : Мысль, 2001.

10. Романова С.И. Художественный образ в пространстве семиотических отношений. Вестник Московского университета. Серия 7 «Философия». 2008. № 6. С. 29.

11. Рудяков Н.А. Основы стилистического анализа художественного произведения. Кишинев, 1972.179 с.

12. Сапаров М.А. Словесный образ и зримое изображение (живопись - фотография - слово). Литература и живопись. Ленинград : Наука, 1982. С. 73.

13. Tartt D. A Secret History. First Vintage Contemporary Edition. New York : Vintage Contemporaries, 2004. 559 p. 


\section{A. MUNTIAN, I. SHPAK. A SECRET HISTORY: CHARACTER ANALYSIS}

The article deals with term "image", which is used in various branches of scientific knowledge. The research dwells on the different aspects of the analysis of the image. This piece is an attempt to research artistic images in the novel "A Secret History" by Donna Tartt. The authors analyze a number of views regarding the artistic image interpretation and emphasize the point that the artistic image has many forms: images of people, pictures of nature, urban landscapes, and images of things reproduced with the help of imagination. The y talk about the origins of creation of the debut novel by Donna Tartt "A Secret History" and point out the specifics of the novel: the story is an inverted detective story, not whodunit, but whydunit.

Key words: notion of image, artistic image, novel, fiction, word, reader's perception.

\section{Анотація}

\section{А. МУНТЯН, І. ШПАК. ТАЕМНА ІСТОРІЯ: АНАЛІЗ ХУДОЖНІХ ОБРАЗІВ}

У статті розглядається термін «образ», що використовується у різноманітних галузях наукового знання. У дослідженні розглядаються різні аспекти аналізу образу. Ця робота є спробою дослідити художні образи у романі Донни Тартт «Таємна історія». Автори аналізують ряд поглядів на інтерпретацію художнього образу та підкреслюють, що художній образ має багато форм: образи людей, картини природи, міські пейзажі та образи речей, втілені за допомогою уяви. Мова йде про витоки створення дебютного роману Донни Тартт «Таємна історія» $\mathrm{i}$ вказується на специфіку роману: історія - це перевернута детективна історія, в якій центром уваги є не злочинець, а його мотиви. Традиційна детективна історія ставить перед читачем завдання розв'язати таємницю/злочин разом із детективом (представник закону чи приватний детектив, професійний слідчий або слідчий-аматор, незалежно). Проте інтрига розслідування та захоплення винного/винних не відіграє основної ролі в даному романі - створення складних художніх образів було головним завданням автора. За допомогою складних художніх образів автору вдається донести весь спектр підзначень до головного сюжету. Сьогодні немає чіткого визначення термінології; їх взаємозв'язок залежить від підходу до розуміння понять літературних образів; нечітка межа між цими поняттями починає розмиватися у зв'язку з появою нових лінгвістичних засобів, що поєднують у собі риси виразних засобів і стилістичних прийомів. Результати дослідження підкреслюють той факт, що поняття художнього образу зароджується у художній літературі, де мова стає як засобом, так і предметом мистецтва; стверджується, що художній образ виступає способом розуміння світу і мови мистецтва. Також продемонстровано, що він має багато форм відтворення: образи людей, картини природи, міські пейзажі, образи речей, які реалізуються за допомогою уяви, втілюються в нових відносинах через конструктивне мислення митця.

Ключові слова: поняття образу, художній образ, роман, художня література, слово, читацьке сприйняття. 